EASTERN REVIEW 2019, T. 8

\author{
Larissa G. Titarenko
}

(iD) https://orcid.org/0000-0002-5729-1430

Belarusian State University, Minsk, Belarus

Faculty of Philosophy and Social Sciences

Department of Sociology

e-mail: larisa166@mail.ru

\title{
Vectors of development in higher education of Russia and Belarus: A comparative approach
}

\begin{abstract}
The article is devoted to the sphere of higher education in two former Soviet countries: Russia and Belarus. It is aimed to compare the systems of higher education in these countries under the angle of global and regional challenges. The article is based on national statistics from both states and survey data. The author analyses the ways that each of the countries' practices to increase its educational competitiveness on the global level and adapt to the market conditions. It is described that both countries use such mechanisms in the sphere of higher education as an educational service for foreign students and membership in the educational associations (European and Eurasian). The scale of the systems of higher education and their potential are described to explain the similarities and differences between the two countries. Three types of educational integration are described. The article concludes that the system of higher education in Belarus is currently developing in a way that differs from Russia and its achievements are much smaller; at the same time, regardless of the declarations on the necessity of internationalisation, current development leads Belarus further away from the European education system, while also not make it closer to Russia. A lack of resources and political dominance over the educational goals make the Belarusian system of higher education not as attractive for students as the Russian one.
\end{abstract}

Keywords: higher education system, Russian Federation, Republic of Belarus, internationalization, Bologna principles. 


\section{Introduction}

The Republic of Belarus is a borderland country which lies between the two big powers of the European Union in the west and the Russian Federation in the east. Due to this geographical fact, it might be natural that Belarus has something in common with both neighbours, in terms of culture; and yet at the same time not want to be dependent on them. Education is an important part of culture. The sphere of higher education is topical everywhere: currently, the economic success of a state depends, among many other factors, on the level of education of its citizens.

Belarus has made some steps forward in both directions, east and west. On the one hand, Belarus has been in a Union with Russia since 1999 (The Union State of Belarus and Russia or simply Union State): there is no visa requirement between these two countries, and according to these agreements young people from both states can study at the institutions of higher education (HEI) in either Belarus or Russia. If young people successfully meet the formal requirements and selection process they can be accepted for free study. If they do not want to pass exams according to the rules of the specific state (these rules differ), they can study with payment: as foreigners. On the other hand, Belarus (as well as Russia) signed the Bologna Agreement; therefore, Belarus has to follow Bologna principles in the sphere of higher education, including academic mobility. Belarusian students can go to particular universities in the EU for a semester (sometimes a year) on the basis of the Bologna principles or another program: Erasmus plus. Although this is not so easy, and the available number of exchanges is not big, this option exists. So, formally, Belarus is "looking East and West" simultaneously. Now, after 20 years of the Union between Belarus and Russia, it makes sense to examine the similarities and differences between the higher education systems (HES) of Russia and Belarus.

The research question is whether Belarus is really getting closer to the East or to the West in the sphere of higher education; i.e. accepts their common approaches and shares their values. The further question arises of which of the two sides Belarus has more similarities within this area. In what follows we will show how Belarus is developing educational cooperation with Russia and EU countries, and what the current results of this process are. We will explain why the Belarusian system of higher education does not resemble any foreign system. The primary goal of this article is to compare the spheres of higher education of Belarus and Russia. The main research instruments include the methods of analysis, comparative and historical approaches. On the basis of a comparison of the national statistical data and surveys results in both countries ${ }^{1}$ we will

\footnotetext{
${ }^{1}$ Our research included expert interviews and students' survey. In total, there were 15 interviews made with the university and Ministry officials, professors and scholars from different
} 
describe the trends in the process of the internationalisation of higher education in Belarus and Russia; show the commonality and differences in their scale and the directions of their efforts to increase competitiveness on a global level of the educational market.

\section{General characteristics of systems of higher education}

Higher education is an important institution in modern society. Under the current influence of global challenges, it is experiencing important changes everywhere. In the post-Soviet region, unlike at previous times, the HES has to meet new demands and serve more functions. Modern universities have to provide knowledge and competences, run innovative research, get profits, orient youth in the market, and educate good citizens for the state.

Systems of higher education in Russia and Belarus are based on Soviet heritage. During the post-soviet decades, they experienced some changes, but still, regardless of the national peculiarities, they have more features in common. They practice similar basic approaches to higher education (centralised control, educational standards, a combination of educating and raising the youth), with various differences in grades, exams, tuition fees, and placement of graduates.

Both states follow similar educational policy and establish similar strategic targets. The national governments are well aware of the new global challenges and understand that, in the conditions of the digital revolution, global competition has significantly increased in the fields of science, technology and education. Therefore, both states developed a strategy for their scientific and technological development that has been adopted. In both countries, there is an active search for ways and mechanisms of change that would preserve national priorities and combine them with the tasks dictated by the global challenges. Thus, both countries emphasise that higher education institutions should train modern specialists who will work effectively in new digitalised sectors of the economy (Putin, 2019; BELTA, 2018b). It is obvious that there are no differences, at the level of strategies and goals of the higher education system, between the two countries.

The admission processes differ in Belarus and Russia, however, due to the Union State, it became possible for their citizens to ease the process of admission and study in each of these countries. This strategy did not become dominant in the educational sphere of two countries. Both systems of higher education (as well as political systems) differ, and there are no plans to make them closer to each other. Theoretically speaking, the reason might be connected to the fact

universities of Belarus. The size of the survey was 620 persons. Other survey results were taken from scientific journals. 
that Belarus is a borderland state situated between the two civilisations (eastern and western, orthodox and catholic), and its foreign policy differs from Russia, sometimes significantly. Politically speaking, Belarusian elites are afraid of becoming more dependent on Russia and loose the real power to make decisions in this sphere. Russia assumes itself as a superpower and tries to dominate in the ex-soviet region, while Belarus plays a multi-vector policy card, trying to "be good" for all neighbours.

There are lots of articles and books on the higher education systems in both states. Still, there are few comparative studies that cover these two systems entirely. A large comparative study of HES in ex-soviet states, that was made some years ago by the Higher School of Economics (Huisman et al., eds., 2017), provided a vivid picture of the development of higher education in each country of this region, while their comprehensive comparison (including a comparison of higher education systems in Russia and Belarus) was less detailed.

The differences in political regime and social-economic policy have caused some peculiarities in the ideology of education. At the beginning of the post-soviet era, the population of both countries was under the influence of liberalism, and shared common transitional expectations. At the same time, Belarusian elites always kept conservative ideas and experienced nostalgia for the Soviet past; therefore, liberal ideas coexisted here with attempts to preserve the "best practices" of the former Soviet system (Batjushko, Vetokhin, 2005). The first post-soviet Law on Education authorised the creation of private higher education institutions (HEIs) and the introduction of fees in state-owned public HEIs. This, in turn, granted more freedom in the choice of programs and disciplines offered by each HEI and replaced the nomination of university rectors with elections (Zakon..., 1991). It does not mean that market principles did not exist here. As in Russia, in the 1990s private education was introduced. Many Belarusian academic actors started private HEIs (since 1994), and new faculties and specialities in the state HEIs were opened. The HES grew fast, trying to meet the increased public demands for expansion. Nevertheless, the system stayed under strong centralised administrative control. Both states stimulated the introduction of private institutions of higher education and the enlargement of state HEIs: it was a tool to shift the youth activities from the economic sphere, which suffered from unemployment, to the sphere of education for several years.

In the early 2000s, the number of private HEIs started to decline. The reasons were numerous. According to some assessments, the main reason for these changes was political and related to the logic of the consolidation of authoritarian power: searching to strengthen its ideological control over higher education and prevent potential students' involvement in political initiatives (Gille-Belova, 2015). Other authors believe that the major reasons were economic and related to the market demands of the public universities to keep a higher level of enrolment (Gaisenok, 
2018). The state HEIs gradually increased the number of students who paid for education and therefore contributed to the state budget.

Later in the second decade of the $21^{\text {st }}$ century, liberal ideas in Belarusian education were critically assessed (Kirvel, 2018) and almost disappeared in the Code on Education (Kodeks..., 2011). Instead, several non-democratic changes were introduced. First of all, the election of rectors that existed for a short period of time was replaced by their appointment. The awarding of bachelor degrees, introduced in the late 1990s, was stopped. In general, according to the assessment of the Independent Bologna Committee, by the end of the 2000s, the HES in Belarus was experiencing a significant lack of academic freedom and university autonomy (Independent..., 2014). At the same time, in one of the expert interviews made by the author in 2018, a high ranking university official expressed an opinion, shared by some other administrative officials, that "the appointment method is better than the free election of rectors because there is no need to decide who is better, and therefore there are no conflicts and competition among the scholars" (Titarenko, Zaslavskaya eds., 2019: 76). This is not common practice: in Russia, some national universities got the right to elect a rector. However, since 2009 the Russian president appoints rectors of the two most famous universities: Moscow State and Saint-Petersburg State; however, their rectors consider this process as being democratic anyway (Viktor Sadovnichii, 2019) because the very term, democracy, is interpreted differently than in the Western countries.

Currently, the private HEIs in both countries are somewhat smaller in size than the state HEIs. Private universities are mainly focusing on social-economic disciplines: economics, political science, languages, or business studies. They are often deemed to have a worse reputation due to lower funding and ranking. However, there are some important exclusions in Russia where some private schools are very popular and more attractive for those who lost trust in the public HEIs - for example, the European University in Saint Petersburg.

Although political alliances usually stimulate a kind of unification in HES, this is not the case for the Union of Russia and Belarus. Both countries keep their full independence and in principle do not want to be unified in any aspect of educational activities. Whilst legally, any young citizen of Russia can ask for admission to a university in Belarus and vice versa; in reality, young people have to pass the entrance procedures that are specific to Russia or Belarus. In Russia, graduates of high school have to pass the so-called Unified State Exam and submit the results to a particular HEI. This can also be used during the process of submitting an application to other HEIs. The Russian Ministry of Education and Science $^{2}$ often discusses the issue of how many institutions a young graduate can

${ }^{2}$ The Ministry of Science and Higher Education of the Russian Federation is a ministry established in May 2018 as a result of splitting the Ministry of Education and Science, which existed 
apply to simultaneously (in some years the number was 3 , in some others 5), but nevertheless, the procedure is simple, and no additional documents are required.

In Belarus, there are two independent processes: graduation from high school with traditional exams, and the admission to the institutions of higher education. For the latter at least 3 (and sometimes 4) recent results of the Centralised Tests (CT) on a particular discipline are required. Centralised testing is the main stage of the admission process in Belarus: applicants pass tests in selected subjects in June. With certificates on the passage of CT, they then submit documents to the selection committee of a particular university. For those young people who do not plan to continue education, the CTs are not necessary. Testing is organised throughout the country each spring. For each speciality, specific subjects are required. Also, some faculties of "creative professions" (painting, music, journalism) ask for additional materials or arrange a "creative competition" for applicants. Usually, the results of the CT are valid for one year, so, those who failed the $\mathrm{CT}$ or were not accepted during the competition, have to pass similar CT exams again the following year. A young Russian high school graduate cannot be accepted without such results for free education, as a citizen of the Union; however, they can apply as a foreigner and pay for education. And the same problem occurs with a young applicant from Belarus in Russia. For this very reason, most Belarusians study in Russia as foreigners, and Russians also pay the fees in Belarusian HEIs.

Belarusian university graduates who have been educated on a budget basis receive state distribution and their first employment, which is not the case in Russia. This is a significant difference between the two countries which is negatively estimated as a relic of the Soviet past by the supporters of the liberal approach (Belaya kniga, 2018).

\section{The scale of the higher education and number of students in Russia and Belarus}

A modern approach to the assessment of the countries focuses on the comparison of their human capital and their ability to save and expand it. Therefore, we will start with a comparison of Russia and Belarus by this factor.

If we look at the Human Development Indices and Indicators (Human..., 2018), in 2018 Russia had a higher rank of HDI (49) than Belarus (53), out of 189 countries. The main indicator that determined a higher rank for Russia was income: Russian gross national income (GNI) per capita is $\$ 24,233$ while

from March 2004, into the two agencies. The second agency which simultaneously emerged is the Ministry of Education. 
Belarus has only $\$ 16,323$. At the same time, such an educational indicator as "mean years of schooling" is slightly higher in Belarus (12.3 years vs. 12.0 years), and a second indicator, "expected years of schooling", is equal in both countries (15.5 years). In general, Belarus and Russia have similar ratings and educational potential in the sphere of human development. If we compare them with the HDI in Poland, the latter is higher: the Polish rating is 33, with 16.4 "expected years of education" and 12.3 "mean years of schooling". However, these formal indicators do not provide a whole picture of the situation in higher education.

The important indicator of educational success is the number of students. This factor depends on the demographic development of a country. In general, demographic trends in Russia and Belarus are similar, but not exactly the same: the size of the population of the two countries is not comparable; nor is their ethnic composition, which also influences the birth rate and, indirectly, the sphere of higher education.

The educational level of youth is important for comparison. In the European Union, the proportion of the population that reached the third stage of education (according to the international classification system of education, levels 5-6) in the population of 30-34 years is often considered. This group includes specialists who completed special secondary and higher education. In the European Union (EU), this share averages $35.8 \%$. In Belarus, national statistics do not use this indicator. According to some calculations, this share is extremely high: around 59\% (Bogdan, 2018: 582). However, the share of the state expenses for this level in the structure of all expenses for education in Belarus steadily decreases. In relation to GDP per capita, this share of expenditures in Russia and Belarus is $0.9 \%$, which is significantly lower than in EU countries (on average, 1.3\%) or other highly developed countries of the world. Russia spends a third more financial resources for training one third-level student than Belarus, although the percentage of gross domestic product (GDP) spent on higher education in Russia and Belarus is almost identical: $14 \%$ and $15 \%$. In 2018, according to calculations, the cost per third-level student in Belarus was $\$ 2,763$, in Russia - \$3,900 (Bogdan, 2018: 583). Both countries fund higher education to a lower degree than the EU. Meanwhile, the inadequate funding for higher education at this level leads to a decrease in its quality and a possible outflow of promising young people to study abroad. Indeed, many Russian students study abroad, especially in the US and the EU. For example, only in 2016, there were 10,000 students from Russia in Germany; more than 5,000 in the US; more than 4,000 in the UK; and 3,600 in France (Obrazovanie v tsifrah, 2018: 47). The official statistics of this kind are not available for Belarus, although many young people study in Poland and Lithuania.

Due to the huge difference in the population of Russia and Belarus, the number of students is also in favour of Russia. For example, in the 2016/2017 academic year, according to the published statistics, 4,399 million people studied in Russia at two levels of higher education, and the state financing on education in total 
reached 3.6\% of GDP. More than 30\% of the population aged 25-64 had full higher education. The government spending on higher education accounted for $1.6 \%$ of total government spending, or $0.6 \%$ of GDP (Obrazovanie v tsifrah, 2018: $11-12,16,22-23)$. At the beginning of the 2016/2017 academic year, there were 818 universities in Russia, of which 316 were non-state (almost 39\%) (Obrazovanie $v$ tsifrah, 2018: 33). At the beginning of the same year, 3,263 million people were studying under the bachelor's program, 0,689 million people were studying under the specialist program, and 0,447 million people - under master's program (Obrazovanie v tsifrah, 2018: 44).

In Belarus, the number of students among the young people of this age group is $91.5 \%$ (higher than in Russia). Practically, all the school graduates, wherever they live, have no admission barriers to entering universities. It is not by chance that, according to the latest data of the World Bank, the rate of school graduates enrolled in Belarusian universities reaches $87 \%$. Higher education has become publicly available (Spasjuk, 2014). However, mass education has led to a decrease in the quality of education and its social status. The level of knowledge of the applicants decreased, as well as their learning outcomes in high school. Many cannot pass CTs with good grades and therefore have to pay for HEIs or go to private HEIs where admission is easier (Gaysenok, 2018).

As the number of young people graduating from high school declined, several private schools were closed (they could not get new state licenses). In order to keep the high level of students, the state has increased the number of budget places in the state universities: from 2010 to 2018 it increased from $33.8 \%$ to $43.8 \%$ (Obrazovanie v tsifrah, 2018: 40). Several inefficient universities were closed due to poor results of accreditation. Currently, there are 51 HEIs (42 state and 9 private). According to a decision of the Ministry of Education, this number will not be reduced in the nearest future in order to ensure access to HEIs throughout the territory of Belarus. At the same time, 28 out of 51 HEIs are located in Minsk, therefore half of students study in the capital and try to stay there after graduation.

Study programs differ, as well as the number of students in each program. In Belarus most students graduate as specialists (MCKO 6) - 96.3\%, and much less go on to master's level (ISCE 7) $-2.3 \%$ or PhD level (ISCE 8 ) - 1.3\% (Belaya kniga, 2018: 11). This disproportion means that the lower level of higher education is much more available in Belarus than the other two. The drive to make higher education available to the masses had led to the cancellation of special programs in order to give admission preferences to rural students in Belarus. This, in turn, has caused a general decrease in the knowledge of applicants (Gaisenok, 2018).

Other changes include the assessment systems (5-grades in Russia and 10 -grades in Belarus), and degrees. The bachelor degree does not exist in Belarus, however, the specialist study program is only for 4 years, unlike in Russia where bachelors study 4 years and specialists -5 years. 
Still, due to a high level of centralisation, HES have preserved the procedure of the state approval of educational standards and study programs in both state and private HEIs, as well as state accreditation for them.

\section{Internationalisation in higher education}

An important feature of the educational activity initiated by the market economy is selling the educational service to foreign students. In the USSR it was common to invite young people from developing countries to study in the Soviet institutions of higher education for free. It was a kind of foreign policy of the internationalisation that was in line with Marxist ideology. Now everything can be done on a commercial basis - with payment, although some additional agreements between countries, that reflect their preferences in the foreign policy, also exist. We will describe the scope of the process of internationalisation in both countries, and its major directions.

Under conditions of the new global challenges and regional tasks, facing the field of higher education in the ex-soviet region, there is an active search for ways to increase the level of the competitiveness of the systems of higher education in Russia and Belarus.

Both countries try to attract foreign students to their HEIs; however, with different results that reflect their different economic and political roles in the region and the world. Russia ranks seventh in the world in the global education market. According to the data for the 2016/2017 academic year, the number of foreign students exceeded 313,000 people, which amounted to $5.7 \%$ of the total number of students in Russia. Of course, Russia cannot be compared with the leader in the global education market: the USA, with a share of foreign students of about $20 \%$ (Aref'ev, 2018: 305). But in the Eastern European region, no country can compete with Russia. The average annual rate of increase in the number of foreign students over the past 10 years, according to the same source of information, was $9.6 \%$. The fact that the first four main countries (both post-Soviet and others) sending students to Russian universities are located in the Asian region means that the Asian direction has become dominant in Russia's foreign education policy. Judging by the development trends of educational regionalism, this direction is unlikely to change in the coming years.

Until recently, the increase in foreign students in Russia came mainly from post-Soviet countries. During the period from the academic years of 2004/2005 to 2016/2017, these countries accounted for three-quarters of the total growth of full-time foreign students and $100 \%$ part-time foreign students in Russia. The leaders in this group were Kazakhstan (more than $20 \%$ of all foreign students) and Turkmenistan (under $9 \%$ of foreign students), and Belarus was in the seventh 
place in this row (4.2\%). Some changes in this hierarchy are possible because the number of Ukrainian students in Russia has been recently declining (in Belarus the number of Ukrainian students has never been significant). Currently, the total number of foreign students is $5.7 \%$ of all students in Russia.

The main source countries outside the post-Soviet region are China $(8.7 \%$ of all students in the 2016/2017 academic year) and India (3.1\%) (Aref'ev, 2018: 313). Most foreign students study at bachelor and specialist levels. A significant proportion of foreign students in Russia are studying engineering and medicine. Their common problem, often leading to dissatisfaction with the education they receive, is poor knowledge of Russian (recently it has become a problem for students from some post-Soviet countries as well), which inevitably affects the quality of education (Aref'ev, 2018: 320).

In Belarus, the number of foreign students is much less, and their growth rates are smaller than in Russia. Thus, in the 2010/2011 academic year there were 9,357 foreign students in the universities of Belarus, and 15,506 in 2018/2019. Half of these students were from Turkmenistan. However, in 2019 the Turkmen government made a decision not to recognise several higher education degrees from former Soviet states (for example, in business, law, and political science). In the case of Belarus, the Turkmen government allowed Turkmen students to study only in a few Belarusian HEIs. This decision will definitely decrease the number of students from this country soon. Other big groups of foreign students are from Russia (9\%) and China (7.2\%). This hierarchy has changed during the aforementioned years because the foreign countries change their preferences quite often. In 2010 the number of Russians was $23.5 \%$, Turkmen $-36.4 \%$, and Chinese $-13.1 \%$. Recently a significant shift towards the East took place. The total number of foreign students accounted for $5.8 \%$ of the total number of students in the Republic of Belarus (Obrazovanie v tsifrah, 2018: 41).

There is a significant exchange of students between Russia and Belarus beyond the official programs. The balance of such exchanges favours Russia. In the academic year 2017/2018, statistics indicated around 1,500 Russian students in Belarus, while the number of Belarusians studying in Russia (mostly as parttime students) was 10 times higher. Such "student exchanges" are popular in the regions (oblasti) near the border. Belarusian authorities do not care about this unequal exchange as they cannot stop it or change this tendency.

Belarusian regional initiatives have been determined by the economic interests and directed mainly to more distant countries with a lower level of higher education or a higher level of fees for students. Another aspect is political: Belarus prefers to cooperate in the educational sphere with its political partners. Overall, Belarusian authorities sought to enlarge the educational market for their own country and sell Belarusian educational services to their economic and political partners. Study programs in the Russian language make Belarus attractive for those students from former Soviet states who mostly come from 
families with a good command of Russian. Moreover, Belarus has a reputation for being a safe country that provides foreigners with peaceful and comfortable conditions for studies.

The Belarusian HES is known and respectful among many Asian countries as it provides relatively good education, especially in medicine, for a moderate price compared to other countries or less (in comparison with Russia). Two countries, Turkmenistan and China, account for the two largest groups of Asian students in Belarus (7,200 and 1,400 people respectively). Thanks to bilateral agreements, foreign students are only required to pass an interview to demonstrate their proficiency in Russian, the language of most courses of study. Preparatory Russian language training is also available prior to degree programs (Titarenko, 2019: 6). Currently, around 5\% of all students in Belarus are international; and the opportunity for further growth exists. However, programs in English are rare which makes education in Belarus less attractive for students from many countries.

\section{Eurasian integration}

The search for the new appropriate forms of educational cooperation is continuing. It has been expected that construction of the Eurasian Economic Union will increase cooperation between its members in higher education. However, it did not happen because Belarus (and Kazakhstan) were afraid of the increasing youth brain drain to Russia in case of a higher level of educational cooperation. Russian foreign educational policy is very active. Several Russian universities established bilateral and multilateral MA programs to train Russian and foreign students for employment in the popular spheres of work within the Eurasian region. This kind of cooperation at the inter-university level is on the rise, involving the new educational actors from Russia; and this trend will continue. Belarusian universities do not participate in this initiative. So far, in regard to Russia and Belarus, European integration and Eurasian integration are less developed, than the Asian direction of their foreign educational regional initiatives. On the basis of the past Soviet heritage, integration within the Eurasian economic space (EAES) has started to spread. Russia is a leading country in this process.

Russian branch campuses, as a form of educational cooperation, are typical. Belarus is less active. It protects its territory from any foreign HEIs. For this reason, Belarus has no branches from the EAES and only one joint Belarusian-Russian HEI (in Mogilev). Belarusian campuses and branches do not exist abroad as well; either in Russia or in other countries. The main reasons for this policy are economic: a lack of finance for such initiatives and a lack of assurance that they will be profitable for Belarus. On the 
contrary, Russia actively uses its soft power: it opened several branches of its universities in the post-soviet region to promote the internationalisation of education: such branches are considered to be a soft power of Russian international foreign policy and a regional integration strategy in the global educational competition. Russia is among the first five global exporters of the international branch campuses. During the post-Soviet period, according to a study, 58 branch campuses were established by Russian universities in 12 ex-Soviet republics (Abbasov, 2019: 14). It is clear that Russia took the lead in fostering cooperation and educational integration in the post-Soviet region.

Russia has also organised a joint educational forum with ASEAN, after which an ASEAN-Russia Working Group on Education was launched (2018) to work on strengthening cooperation amongst the ASEAN educational network. Similar university cooperation started with the countries from other regions in Asia. In general, Russia "sees itself as an important player in maintaining and extending educational opportunities" (Sabzalieva, 2019: 8). It also increases cooperation with the members of the Eurasian Economic Union, opening and supporting joint universities in these countries and the regions beyond Eurasia (BRIKS, Global South). Russia has put forward a similar goal in its educational policy as the EU: to be among the global leaders in the education market.

If we compare the ranks of the universities within the members of the EAES, we will see that all the universities on the top positions among the Eurasian union states belong to Russia. This is a confirmation of Russia's higher level of scientific development at universities, better financial investments, a greater number of articles published in journals indicated in the Scopus system, and a higher level of quotations of the articles per person among the academic staff (Gaisenok et al., 2019: 40-41). Therefore, in the near future, all the comparisons in the sphere of higher education in this region will be in favour of Russia.

It is worth mentioning the positions of Russian and Belarusian universities in the most famous world ratings published in 2019. According to the Times Higher Education (THE) rating, only the Belarusian State University (out of all 51 Belarusian universities) was included in this list of the world's best universities, and its place is rather low (among the 1,350 universities it is in a group of 1,000+, while in 2017 its place was in the group of $800+$ ). Russia is represented by 39 universities. The best Russian university is Moscow State: it occupies the $189^{\text {th }}$ place. Over the last few years, five new Russian universities have been included in this rating while a second Belarusian university, Belarusian National Technical, lost its position in THE in comparison with the previous years. For comparison: the best Polish universities, Jagiellonian and Warsaw universities, are in the group of $600+$, and 12 other universities are included in THE as well. As for the other popular world ratings: only two HEIs from Belarus are included in the Quacquarelli Symonds (QS) rating, however, they hold very low positions in QS. 
Three Russian HEIs are in the first 1,000 universities according to QS. Two best Russian universities are included into the third most important global rating, the Academic Ranking of World Universities (ARWU), where Belarusian HEIs are not selected (BELTA, 2019; Gaisenok et al., 2019).

\section{European integration}

The Bologna process currently unites 48 countries. Bologna provides the framework for international cooperation between universities, and facilitates the dissemination of the best regional experience in higher education. Its official goal is the creation of common space for higher education in Europe and the opening of new opportunities for graduates to be employed in the EU labour market. Russia and Belarus are members of the European space of higher education: Russia entered it in 2003, aiming to harmonise European education standards, and Belarus joined in 2015; being the last European country to do such.

The Bologna reforms were gradually introduced in Russian HEIs, starting with the 3-level structure, so that now Russia has the levels of bachelor's, master's and PhD studies. "Specialists" also exist, but they are in a minority. In Belarus bachelor's degrees do not exist: graduates from 4-year courses are called specialists, similar to the previous 5-year course. In 2018 the Ministry of Education in Belarus reduced master's programs from two to one year, with a significant part of classes becoming distance-learning. The Belarusian academic public accepted this change because the students' motivation to continue education immediately increased. Our new survey (2019) discovered that young people did not want to spend 2 years doing master's studies because there is no difference in the employment between the graduates of the two levels. The expert interviews showed that the university staff were not aware of the principal differences between the courses at the first and second levels, and how to control and check the independent student work at the Master's level. This lack of experience has led many teachers to a deadlock - similar to one that Russian university staff experienced in the early 2000 s, after the introduction of the Bologna system (Zborovsky, 2018: 99). Probably, the implementation of Bologna innovations in Belarus would also take more time before they bring visible results. Currently, there is a concern that the reduction of master's studies to one year can make the two-level structure of higher education similar to the previous 5-year education model and practically prevent the renovation of the old scheme in higher education. More importantly, however, this is not a solution for another problem - the lack of the students' motivation to study. This question, in turn, leads to the high school system and its similar problems of motivation and quality of education 
in both countries. According to Russian sociologist G. Zborovsky (2018: 100), it is necessary to search for "new learning technologies that would allow students to be interested more and more than today...". Still, it is obvious that as long as the students' knowledge received is not closely correlated with the future income earned and professional career gained, motivation will remain low, regardless of any educational structures.

Scholars in both countries are concerned about the particular Bologna principles and their implementation. Thus, the students' mobility depends on the quota given to the country and on the available financial support from the students' families. Under the poor economic conditions in Belarus, as well as in the Russian provincial cities, many students cannot cover the costs of long-term travel abroad. Russian scholars further argue that their provincial universities are poorly financed (Zborovsky, Ambarova, 2019). The level of participation in the mobility programs run by the Russian Ministry of Education and Science is also small (Poleshchuk, Ridiger, 2018).

In Belarus, according to expert interviews, fewer students are ready to travel than earlier because of financial reasons. What is more, the level of both the staff and student's knowledge of Bologna principles is poor in both countries (Motova, 2018; Titarenko, Zaslavskaya, eds., 2019). According to our surveys, almost half of Belarusian students do not know about Bologna innovations, and one third cannot assess the impact of Bologna principles on the Belarusian HES. Indeed, the visible results include mainly reduced terms of study at the first level and ECTS, travel and academic freedoms are less visible (Sechko, Romanova, 2017) That said, the participation of the staff and students in the management process was implemented formally; the distribution of Belarusian graduates financed by the state budget is still determined by law. Alas, however, the national structure of qualifications is not in harmony with the new structure of higher education, so that a second-level degree does not guarantee better employment or a higher salary (Motova, 2019; Belaya kniga, 2018).

The important issue related to the transformation of universities is quality assurance. Firstly, it is connected to the state accreditation of HEIs: the state has the right to close any HEI due to its low quality. Secondly, it is connected to the market demands: according to expert opinion, the selected quality assessment methods have to meet the demands of the future employers as they need young specialists with particular knowledge, competences and skills (Glebova, Gus'kova, 2012: 2-5). This problem is common for both Russia and Belarus. Many university experts expressed their concerns that the rapid introduction of Bologna principles and new methods of quality assessment in the educational sphere made it difficult to select the best approaches to quality assessment, taking into account the specificity of a particular Belarusian HEI (Titarenko, Zaslavskaya, 2019: 79). For this reason, the national administration tries to modify Bologna principles and make them suitable for the common national practice and compatible with the national 
priorities in education: patriotism, national identity, national history (Marzaljuk, 2018). Practically, these are two different ways to interpret and assess the quality of education. As the Belarusian Minister of Education explained the dominant approach, we have to accept the foreign best practice and at the same time keep our full independence (Karpenko, 2017). This complexity and formal acceptance of foreign practice lead to the fact that university administration prioritises national approaches to the quality of education and the HES in general.

Regardless of any approaches to this process, according to the literature, universal methods in quality management do not exist. The applied methods in both countries often lead to a decrease of the HEIs' competitiveness because the HEIs fail to select the best practices and have no incentives to motivate the staff to work better (Korzavina et al., 2016). The plurality of formal indicators of quality cannot bring systemic results and help to improve the educational process.

The European Higher Education Area offers its members a possibility to establish the double degree programs that would allow the students to simultaneously obtain two degrees from partner universities in two countries. Russia has been included in such practice, although there exist numerous financial and formal obstacles for its proper implementation. In Belarus, there are no double programs even between the universities within the Eurasian educational space. The first program of this kind was recently announced for MA students in history: it is planned to start this program between MSU and BSU, however, only as a pilot project. Therefore, many highly motivated students from middle-class families prefer to study abroad and receive degrees issued in the EU or US. This is an example of how economic conditions may cause obstacles for the implementation of the best foreign practices because this process would require much more financial investment and more international communication with the best foreign HEIs.

\section{A common problem - different approaches}

For the last few years, Belarus has experienced significant economic problems that influence all other spheres, including higher education. The level of state funding has decreased. Therefore, the Ministry of Education has been trying to make HE less expensive for the state budget and more oriented to market needs. The strategic goal is to connect higher education with business so that the latter pays for the young professionals that are in need in the economic sphere. According to this strategy, the Belarusian Ministry of Education put forward a goal "to construct an educational system of high quality to fully meet the needs of the innovative economy and sustainable development" (Conceptual'nye..., 2017).

However, the existing system of HE is not ready to perform the new strategic tasks in full because they demand a lot of financial investments. Thus, the head 
of the National Academy of Sciences of Belarus, academician Vladimir Gusakov, mentioned in his interview:

If we want to receive a new quality, it is necessary to invest a lot of quantitative goods: resources, means, intellectual capital, to create the appropriate material basis, train the personnel. This is not a one-stop action (Gusakov, 2014).

Unfortunately, this statement did not become the key to a substantial improvement of the situation in higher education. Currently, this system still badly needs a higher level of state financing for the practical implementation of the above-mentioned strategic goals. In 2018 an expert survey was carried out amongst university personnel and administrators of different levels employed at the HEIs in Minsk, and several regional cities. The survey helped us to demonstrate that the Belarusian HES cannot be quickly modernised to meet the global challenges (Titarenko, Zaslavskaya, 2019). The Belarusian HES itself (as well as the Russian HES) is a part of the institutional system and it is fully subordinated to the state structures. Universities are not able to change their educational programs and introduce new specialities to meet the demands of the innovative businesses, without decisions being made by the Ministry of Education, that also depends on the decisions of the Council of Ministries, etc. Such changes require lots of time and effort. Even private HEIs are dependent on the state with regards to strategical issues. Taking into account the quick changes in the situations in the conditions of global competitiveness, it may happen that educational innovations will be allowed too late and become obsolete.

This situation is typical for most Belarusian HEIs, that practically cannot meet the demands of the market as these demands themselves are quickly changeable, and the HES cannot adapt to them quickly enough. In Russia the corporate business opened some private universities for its own needs, these HEIs are out of the control of the Ministry of Education; whilst the rest of Russian HEIs experience problems similar to Belarusian HEIs.

Under conditions of high uncertainty in the Belarusian economy, it is not possible to predict what will happen next. Currently, the state demands to shift the higher education closer to the practical needs and even cut some theoretical university courses in favour of increasing the practical training programs. A new step in this direction is connected to the model of the entrepreneurial university ("university 3.0") that was introduced in the Belarusian HES a few years ago (BELTA, 2018a; Pashkevich, 2018). Using this model, we will show the differences in its implementation in Belarus and Russia, where this model became known earlier but still was not officially imposed on the HEIs. The meaning of the model "university 3.0" is to add a third mission to the university - marketable, or entrepreneurial. Universities have to establish close ties with industrial institutions to perform R\&D and create marketable products. 
It is assumed that universities have to open new laboratories and industrial structures; they have to invite practitioners and students to work together in these laboratories and produce innovative goods and services. Ideally, representatives of Big Business have to be incorporated into the university councils and take part in the educational decisions with regards to the study programs. Becoming a part of the university-industrial complex, businesses will invest their own money into education and later employ the specialists trained according to their needs. Practically, such complexes will not be universities anymore; they will be business corporations. It will mean that universities will gain profits and become fully commercial structures dependent on business and the market.

This model is known from the late XX century when it was researched in detail by B. Clark. This scholar described 5 cases of such universities and concluded that it is acceptable mainly for technical universities with a highly applied orientation to the market. It means that this model is not universal: it is limited by the existing specialisations of study and depends on many conditions (Clark, 2011). Even in the case of the successful implementation of this model, it is not a guarantee of commercial success being replicated by another HEI. Also, it cannot guarantee the international success of the HEI, measured by the global ratings, high quality of education or number of publications in the Scopus journals.

Regardless of the existence of theoretical and practical literature on the limits of "university 3.0", this model is currently imposed in Belarus in 8 universities (among them 2 classical and 2 pedagogical). At the same time, the scholars from the non-state organisations who are well aware of this model warned the government that it was a wrong decision to broadly develop the entrepreneurial vector of development for Belarusian universities due to the low level of innovation in Belarus (Kolesnichenko, 2019). However, their experience and assessments of this model were not counted by the government.

In Russia, this model is supported by technical HEIs. The classical HEIs that train both specialists and young scholars reject this model because the orientation of HEIs to the clients makes it impossible to prepare the new generation of scholars (Popova, Klimova, 2018). Unlike in Belarus, the commercialisation of higher education in Russia is broadly discussed in the journals and in public, and is not considered to be a universal answer (Erovenko, 2019; Andrianova et al., 2019). As for Belarus, some critically oriented scholars protest against the transformation of HEIs into commercial organisations that provide diplomas for money, as it contributes to the "transformation of education into a service sector, and the university professors into teaching waiters providing these services" (Kirvel, 2018: 93). To summarise: the practical introduction of a model of an entrepreneurial university can increase inequality between the universities, while it can also contribute to their competitiveness and the diversification of investors in the case of technical universities. 
The major indicators of the non-universal character of different models of the commercialisation of the HES, and the uncertain results of the market approach to the sphere of higher education, are the low global ratings of HEIs that already used these tools (at least, these universities did not improve their ratings automatically after the implementation of this approach). When the model "university 3.0" was introduced in the best Belarusian HEIs, such as Belarusian state and Belarusian Technical national universities, their ratings fell. In Russia the best HEIs with the highest ranks belong to the classical universities; however, some technical universities also reached a high level; they are better visible within the universities of the Eurasian educational space where all top positions belong to Russian HEIs (Gaisenok et al., 2019).

\section{Conclusion}

Answering the research question put forward at the beginning of this article, it is possible to conclude that the Belarusian HES is not getting closer either to the Russian or Western HES: it tries to follow its own way. In practice, this way is not more efficient but it reflects the country's current national priorities.

Comparing the development of the HES in Russia and Belarus, one can assume that the Russian HES is more effective in the global, regional and domestic sphere: several Russian research and federal universities reached high world ranks; they attract lots of foreign students to study and invite foreign staff for collaboration. The Belarusian HES cannot attract the best foreign staff and students at the same level as Russia, as it has much less finance from the state - its principal investor. The diversification of its funding base and development of the entrepreneurial culture is on the agenda in Belarus, but far from a reality.

Belarus lags behind Russia in the pace of the transformation of the HES aimed to increase its global competitiveness and adaptation to the digital economy. The high level of the centralised control over the HES in Belarus has slowed down the process of its modernisation. Firstly, such control hinders the practical introduction of the best practices selected by the administration of a particular university. Secondly, the attempts of the Belarusian government to fully control the changes in the HES did not contribute to the improvement of its quality and the motivation of the students. Russia provided more autonomy to its best (federal) HEIs, which made these universities more competitive and effective. The Russian HES more quickly implements the changes associated with the advancement of science, the entrepreneurial university, and the diversification of funds; although only a part of the universities are included in these innovative processes. Russian universities are more active in global international cooperation and use a variety of methods that do not exist in Belarus (double degrees, branch 
campuses, joint universities). However, provincial universities in Russia are also under-financed and losing students.

Still, the two educational systems share similarities that set them apart from other countries. Most importantly, both countries provide unyielding support for their national priorities in higher education, even if it prevents the implementation of Bologna principles or their own declarations about unified approaches to education within the Union of Russia and Belarus. While developing their foreign educational policy, both countries are "moving East" following their own different ways: most foreign students are from the Asian region. European educational integration keeps its importance in the alignment of the HES structure and increasing its competitiveness, but it is not promising for recruiting students from the EU.

\section{References}

Abbasov, A. 2019. The emergence of Russian Branch Campuses in the Post-Soviet Space as Regional Integration Strategy. Higher Education in Russia and Beyond. Regionalism in Higher Education 1, pp. 13-14.

Andrianova, E.B., Davydenko, V.A., Romashkina, G.F. 2019. O posledstvijah reform v obrazovanii (rezultaty konferencii «Obrazovanie, molodezh, konkurentosposobnost»). Sociological Studies 1, pp. 150-152.

Aref'ev, A.L. 2018. Mezdunarodnoe obrazovanie v global'nom i rossiyskom izmerenii. In: Obrazovanie i nauka v Rossii: sostojanie i potencial razvitija. Sb.statej, vyp. 3, Moskva, pp. 301-327.

Batjushko, V.I., Vetokhin, S.S. 2005. Tendencii i pervye resultaty Bolonskogo processa. Vysheyshaja shkola 5, pp. 4-12.

Belaya kniga. 2018. Evropeyskie perspectivy belaruskago vysshego obrazovaniya,Vilnius: VŠI «Socialinès ir politinès ekspertizès agentūra».

BELTA. 2018a. Belarus has all the conditions for the implementation of the University 3.0 model, http://www.belta.by/society/view/v-belarusi-sozdany-vse-uslovija-dljarealizatsii-modeli-universitet-30-karpenko-286240-2018/ (accessed 20.04.2019).

BELTA. 2018b. Rezoljucija II S'ezda uchenyh Respubliki Belarus, http://www.belta.by/ printv/society/view/rezoljutsija-iisjezda-uchenyh-respubliki-belarus-284062-2018/ (accessed 11.01.2018).

BELTA. 2019. BSU voshel $\mathrm{v}$ novuju versiju mirovogo reitinga universitetov THE. https://www.belta.by/society/view/bgu-voshel-v-novuju-versiju-mirovogo-rejtingauniversitetov-the-361755-2019/ (accessed 12.09.2019).

Bogdan, N.I. 2018. Obrazovanie i nauka dlja innovatsionnogo razvitija stran EAES: Sravnitelnaja ocenka. In: Bolshaja Evrazija: razvitie, bezopasnost', sotrudnichestvo, Moskva, pp. 582-585.

Clark, B.R. 2011. Creating Entrepreneurial Universities: Organizational transformation direction. Moscow: Higher School of Economics. 
Conceptual'nye podkhody $k$ razvitiju systemy obrazovaniyaRepubliki Belarus' do 2020 goda I budushee vplot' do 2030 goda. Prikaz Ministra Obrazovaniya Republiki Belarus' ot 11/29/2017, http://edu.gov.by (accessed 12.02.2018).

Erovenko, V.A. 2019. Social'ny process McDonaldizatsii: primer transformatisii mathematicheskogo obrazovanija. Alma Mater 2, pp. 15-19.

Gaisenok, V.A., 2018. Systema vyschego obrazovaniya v Respublike Belarus: etapy razvitiya i tekushie zadachi. In: V. Kazarenkov (ed.). Vysshaya Schola: opyt, problem, Perspectivy: materialy XI Mezdunarodnoy nauchno-practicheskoy conferencii, Moskva, 1, pp. 23-26.

Gaisenok, V.A., Naumovich, O.A., Samohval, V.V., Galynskiy, V.M., 2019. Mirovye reitingi vuzov: analyz rezultatov s uchetom profilja ih obrazovatelnoy i nauchnoy dejatelnosti. Higher Education in Russia 28(8-9), pp. 36-43.

Gille-Belova, O. 2015. Beyond the Limits of the European Higher Education Area: The Case of Belarus. European Journal of Higher Education 5(1), pp. 83-95.

Glebova, L.N., Gus'kova, M.V. 2012. Podhody k formirovaniju nezavisimoy ocenki kachestva professional'nogo obrazovania, Vyschee obrazovanie segodnja 4, pp. 2-5.

Gusakov V. 2014. By 2030, Belarus will move to the sixth, highest technological order. Interview with Chairman of the Presidium of the National Academy of Sciences of Belarus V. Gusakov from 09/30/2014, https://www.sb.by/articles/v-xxi-veke-vekebiotekhnologii-vazhno-ne-otstat-ot-liderov.html (accessed 25.06.2019).

Huisman, J., Smolentseva, A., Froumin, I. eds. 2017. Twenty five years of transformations of higher education systems in post-soviet countries: reforms and continuity. London: Palgrave Macmillan.

Human Development Reports. 2019. UNDP, http://hdr.undp.org/en/2018-update (accessed 15.03.2019).

Independent Bologna Committee. 2014. Alternativniy doklad. Gotovnost belaruskogo vysshego obrazovaniya $k$ vstupleniju $v$ Evropeyskoe prostranstvo vysshego obrazovaniya, Minsk. http://bolognaby.org/images/uploads/2014/12/альтернативдоклад-2.doc (accessed 10.10.2016).

Karpenko, I.V. 2017. Konceptual'nie podhody k razvitiju systemy obrazovanija Respubliki Belarus. Zurnal Belorusskogo gosudarstvennogo universiteta. Sociologija 3, pp. 44-47.

Kirvel, Ch. 2018. Sovremennoe obrazovanie “v tiskah" liveral'no-rynochnogo extremizma. Zurnal Belorusskogo gosudarstvennogo universiteta. Sociologiya 4, pp. 88-96.

Kodeks Respubliki Belarus ob obrazovanii. 2011. Approved 13.01.2011 № 243-3, http:// www.pravo.by/document/?guid=3871\&p0=hk1100243 (accessed 20.03.2018).

Kolesnichenko, N. 2019. Zachem Belarusi Universitet 3.0?, https://zautra.by/news/news29965 (accessed 15.03.2019).

Korzavina, N.P., Leongardt, V.A., Chikova, O.A. 2016. Konkurentosposobnost' vuzov na rynke obrazovatel'nyh uslug i rynke truda: vzaimosvjaz' komponentov i pokazateley. Pedagogicheskoe obrazovanie v Rossii 8, pp. 144-147.

Marzaljuk, I. 2018. Kak postroit'tsitadel'pravdy, https://www.sb.by/articles/kak-postroittsitadel-pravdy.html (accessed 19.11.2018).

Motova, G.N. 2018. Dvoynie standarty garantii kachestva obrazovanija: Rossia v Bolonskom process. Vyschee obrazovanie v Rossii 27(11), pp. 9-21. 
Obrazovanie v Respublike Belarus: 2018/2019 uchebniy god. 2018. Minsk: National Statistical Committee.

Obrazovanie v tsifrah. 2018. Kratkiy statisticheskiy sbornik. Moskva: Vyschaya Shkola Economiki.

Pashkevich, B. 2018. Implementation of the model of "University 3.0" GU VPO "Belarusian-Russian University”. Vysheyshaja Schkola 6, pp. 21-23.

Poleshuk, O.D., Ridiger, A.V. 2018. Opyt realizacii programmy vneshney mezdunarodnoy akademicheskoy mobilnosti Minobrnauki Rossii. In: Obrazovanie i nauka v Rossii: sostojanie i potencial razvitiya, Sbornik statey, 3. Moskva, pp. 402-408.

Popova, E.P., Klimova, A.V. 2018. Russian universities: organizational specifics and development benchmarks choice. Sociological Studies 2, pp. 63-72.

Putin. 2019. Nam neobhodimy specialist, sposobnye rabotat na peredovyh proizvodstvah, sozdavat i ispolzovat proryvnye technicheskie reshenija. Higher education today 3 , pp. $2-4$.

Sabzalieva, E. 2019. Looking East: Russian regional educational cooperation with Asia, Higher Education in Russia and Beyond. Regionalism in Higher Education 1, pp. 7-8.

Sechko, N., Romanova, S. 2017. Effectiveness of youth policy model in belarus at the contemporary stage of development. Management Theory and Studies for Rural Business and Infrastructure Development 39(1), pp. 86-99.

Spasjuk, E. 2014. Belorusskoe vyschee obrazovanie: pochemu kolichestvo ne perehodit v kachestvo?, https://news.tut.by/society/424109.html (accessed 14.03.2019).

Titarenko, L. 2019. Higher Education Regionalism in Belarus: varieties of initiatives and arrangements. Higher Education in Russia and Beyond. Regionalism in Higher Education 1, pp. 6-7.

Titarenko, L., Zaslavskaya, M. eds. 2019. Modernizatsiya system vyschego obrazovaniya Belarusi is Armenii v kontekste processov Evraziyskoy I Evropeyskoy integracii. Minsk: BSU publishing house.

Viktor Sadovnichii: "Ne soglashus chto v MGU net democratii", https:// www.vedomosti. ru/politics/characters/2019/11/27/817221-viktor-sadovnichii-ne-soglashus (accessed 28.11.2019).

Zakon Respubliki Belarus “Ob obrazovanii”, 1991. Approved 29.10.1991 № 1202-XII, http://pravo.levonevsky.org/bazaby/zakon/text39/index.htm (accessed 15.04.2014).

Zborovsky, G.E. 2018. Modernizatsija obrazovanija skvoz' prizmu socialnoy politiki. Zurnal issledovaniy socialnoy politiki 8(1), pp. 87-104.

Zborovsky, G.E., Ambarova, P.A. 2019. Mechta o horoshem obrazovanii: protivorechija razvitija obrazovatel'nih obshnostey v rossiyskih universitetah. Mir Rossii 28(2), pp. $98-124$. 